\title{
Cut marks on the Middle Pleistocene elephant carcass of Áridos 2 (Madrid, Spain)
}

\author{
J. Yravedra $^{\mathrm{a}}$, M. Domínguez-Rodrigo ${ }^{\mathrm{a}, \mathrm{b}, *}$, M. Santonja ${ }^{\mathrm{c}}$, A. Pérez-González ${ }^{\mathrm{c}}, \mathrm{J}$. Panera ${ }^{\mathrm{d}}$, S. Rubio-Jara ${ }^{\mathrm{d}}$, \\ E. Baquedano ${ }^{\text {b,e }}$
}

a Department of Prehistory, Complutense University of Madrid, Ciudad Universitaria s/n, 28040 Madrid, Spain
b IDEA (Instituto de Evolución en África), Museo de los Orígenes, Plaza de San Andrés 2, 28005 Madrid, Spain
${ }^{c}$ CENIEH (Centro Nacional de Investigación sobre la Evolución Humana), Paseo Sierra de Atapuerca s/n, 9002 Burgos, Spain
${ }^{\mathrm{d}}$ Department of Prehistory, UNED, Senda del Rey s/n, 28040 Madrid, Spain
${ }^{\mathrm{e}}$ Museo Arqueológico Regional de Madrid, Plaza de las Bernardas, Alcalá de Henares, Madrid, Spain

\section{A R T I C L E I N F O}

Article history:

Received 22 February 2010

Received in revised form

4 May 2010

Accepted 14 May 2010

\section{Keywords:}

Taphonomy

Cut marks

Middle Pleistocene

Butchery

Elephant

\begin{abstract}
A B S T R A C T
Áridos 1 and Áridos 2 (Madrid, Spain) are two Middle Pleistocene sites belonging to the isotopic stages 9-11. Both places contain partial carcasses of Elephas (Paleoxodon) antiquus associated to Acheulian stone tools. In this work, the taphonomic study of the elephant remains of Áridos 2 is presented. This study has documented several cut marks on different bones, which indicate bulk flesh and viscerae extraction by Middle Pleistocene hominins. Several arguments are provided to support that at least some of the cut marks were made with handaxes, further suggesting that some of these artifacts were butchering tools in this stage of human evolution. Although cut marks on elephant carcasses have been documented at some Middle Pleistocene sites, very few have been published in detail to allow consideration of their status as hominin-imparted marks. By doing so, the present study provides more evidence of large carcass exploitation by hominins during this period.
\end{abstract}

(c) 2010 Elsevier Ltd. All rights reserved.

\section{Introduction}

One of the recurrent phenomena in Paleolithic archaeology is the spatial association of stone tools and elephant bones in various sites both in Europe and Africa (Villa et al., 2005; DomínguezRodrigo, 2008). From the earliest discoveries during the nineteenth century until the present, several interpretations have been produced to account for this association. Some researchers argued that they were the result of some sites having acted as hunting grounds where hominins were actively engaged in preying on proboscideae (Cerralbo, 1913; Howell, 1966; Butzer, 1972; Freeman, 1994; Howell et al., 1995; Radmilli and Boschian, 1996), butchery places where carcass obtainment strategies were not identifiable (Leakey, 1971), scavenging spots (Shipman, 1986; Binford, 1987; Martos, 1998; Fosse, 1998; Mussi, 2005), or natural traps (Anconetani et al., 1996). Others, more marginally, have argued that several of these spatial associations of stone tools and elephant bones were accidental in nature and not functionally related (Mussi, 2005; Villa et al., 2005; Domínguez-Rodrigo et al., 2007).

* Corresponding author. Department of Prehistory, Complutense University of Madrid, Ciudad Universitaria s/n, 28040 Madrid, Spain. Tel.: +34 9139460 08; fax: +34913946008.

E-mail address: manueldr@ghis.ucm.es (M. Domínguez-Rodrigo).
A hypothesis that has been gaining credibility in the past few years is that regular exploitation of resources from elephant carcasses cannot be documented prior to the European Upper Paleolithic (Frison and Todd, 1986; Frison, 1989; Martos, 1998; Fosse, 1998; Villa et al., 2005; Gaudzinski et al., 2005; Surovell and Waguespack, 2008). Only, exceptionally, at some earlier sites can this activity be documented, probably corresponding to a marginal strategy in hominin subsistence. Middle Pleistocene sites such as La Cotte de Saint Brelade (Channel Island of Jersey) or Lehringen (Germany) are defended by some as places where elephant hunting may have taken place (Scott, 1986; Thieme and Veil, 1985). It has also been argued that if the exploitation of elephant meat were a marginal activity, the exploitation of elephant bones might still have been more frequent for the purpose of manufacturing tools (Gaudzinski et al., 2005; Mussi and Villa, 2008).

This diversity of interpretations is due to the scarcity of taphonomic evidence and absence of arguments that could be used to interpret the association of stone tools and elephant bones properly. Only exceptionally have cut marks and percussion marks on prehistoric elephant bones been documented (e.g., Shipman and Rose, 1983; Villa et al., 2005). Several authors argue that finding this type of evidence is highly unlikely for various reasons. Bone preservation in a large portion of sites is too poor, weathering also deletes part of these traces, the periostium on several bones is too thick to allow stone tools modify bone surfaces, and cartilage, 
tendons, ligaments and the large muscle masses also do not enable frequent contact between stone tool edges and bone surfaces (Villa, 1990; Martos, 1998; Fosse, 1998; Mussi, 2005; Villa et al., 2005; Gaudzinski et al., 2005; Schreve, 2006; Mussi and Villa, 2008). Actualistic butchery observations also show that elephant butchery can be performed leaving very few traces on bones (Crader, 1983; Haynes, 1991). In sum, cut marks on elephant bones are a very uncommon type of taphonomic evidence. For this reason, several researchers have turned their attention to indirect types of evidence such as isotopic analyses, use wear analyses of associated stone tools or the taphonomic study of the context where the elephant bones are found to discuss the possibility of elephant consumption by hominins (Weber, 2000; Schreve, 2006; Mussi and Villa, 2008).

However, the presence of cut marks still remains the most straightforward evidence in support of hominin exploitation of carcasses. This is why the identification of cut marks has to be carried out with utmost care. For instance, the earliest evidence reported for cut-marked elephant bones comes from FLK North 6 (Olduvai Gorge, Tanzania), which was interpreted as a butchery spot (Leakey, 1971; Bunn, 1982). However, the taphonomic reanalysis of the remains has shown these marks to be the result of trampling. No taphonomic arguments can be provided to defend that hominins exploited the elephant remains at the site (Domínguez-Rodrigo et al., 2007). This cautions against the reporting of cut-marked elephant bones without publishing enough information (e.g., detailed magnified binocular or S.E.M. photographs) to show the features necessary to identify such marks as hominin-imparted.

The oldest examples of elephant bones bearing cut marks have been documented in Middle Pleistocene sites such as Ambrona (Spain), La Polledrara and Castel di Guido (Italy), Bilzingsleben (Germany) and La Cotte de Saint Brelade (Channel Island of Jersey). At Ambrona, very few cut-marked bones have been discovered despite the number of elephants, suggesting a marginal but repeated role for hominins sporadically exploiting carcass remains (Shipman and Rose, 1983; Villa et al., 2005). Polledrara and Castel di Guido are known for the artifacts made on elephant bone (Pitti and Radmilli, 1984; Anzidei and Cerilli, 2001), but some of them also bear cut marks suggesting some exploitation of carcasses (Mussi, 2005). La Cotte de Saint Brelade also includes several elephant bones with cut marks (Scott, 1986). Bilzingsleben has yielded several cut-marked elephant bones, among which a foot bone bearing some cut marks on its articular surface is probably the most widely known (Mania, 1990). At Gesher Benot Ya'akov an elephant skull was discovered lying on an anvil, surrounded by stone artifacts, and with some marks above the nasal bone and the occipital suggestive of human exploitation (Goren-Imbar et al., 1994).

Use wear analyses on artifacts from sites where stone tools appear spatially associated to elephant bones have also produced several artifacts suggesting the processing of meat at Gröbern (Germany) and Áridos 2 (Spain), which enables conjecture about the exploitation of elephant meat by hominins (Weber, 2000; Ollé Canellas, 2005).

In favor of the argument that a scarcity of cut-marked elephant bones does not necessarily imply marginal use of elephant carcass resources, it should be stressed that cut-marked elephant bones are also scarce during the Upper Pleistocene (Nývltová Fišáková, 2005). At Mousterian sites such as Kulna (Moravia) or Santo Antao do Tojal (Portugal), there is taphonomic evidence supporting hominin exploitation of elephant carcasses. At Kulna, some possible cut marks were identified (Moncel, 2001) and at Santo Antao do Tojal, two small flint flakes were located embedded in one of the femur fragments (Zbyszewski, 1943), although they could be located in such a position by post-depositional sedimentary processes, given the fluvial context of the site (Sousa and Figueiredo, 2001). In the Gravettian sites of Krakow Spadzista Street b and Milovice G (Poland), a few cut-marked bones were found (Svoboda et al., 2005). Late Pleistocene sites such as Algar de Joao Ramos (Portugal), Gontsy (Ucraine) and Lugovkaye (Russia) have also yielded few cut-marked bones (Zbyszewski, 1943; Sousa and Figueiredo, 2001; Maschenko et al., 2003; Zenin et al., 2003; Iakovlevaa and Djindjian, 2005).

This work expands previous evidence of elephant cut-marked bones by reporting newly found cut marks on bones from the Middle Pleistocene site of Áridos 2 (Spain) (Santonja et al., 1980a,b, 2001; Villa, 1990). Our study shows the presence of cut marks on some bones from the articulated partial carcass of an Elephas antiquus uncovered at the site. This increases the number of Middle Pleistocene sites where elephant butchery is reported and well documented.

\section{Location and characteristics of Áridos (Arganda, Madrid, Spain)}

Áridos 1 and 2 are situated to the left margin of the Jarama river to the southeast of Madrid (Fig. 1). The micromammal study suggests that the sites can be placed within the isotopic stages 9-11 (López Martínez, 1980; Santonja et al., 2001; Sesé and Soto, 2002). Both sites are located in a floodplain (overbank facies) (PérezGonzález, 1980; Pérez-González and Uribelarrea, 2002) and both bear lithic artifacts spatially associated with partial elephant carcasses.

In Áridos 1 a surface of $112 \mathrm{~m}^{2}$ was excavated exposing two paleosurfaces (Santonja and Querol, 1980a). The articulated carcass remains of an E. antiquus was found on the oldest paleosurface, concentrated in an area of $50 \mathrm{~m}^{2}$ (Soto, 1980; Santonja and Querol, 1980b). A total of 331 lithic pieces and mandibular fragments of two bovids were also found (Santonja and Querol, 1980a). Bone surfaces are mostly moderately well preserved. The lithic assemblage is characterized by the abundance of flakes and some refitting was successfully carried out (Santonja et al., 1980a,b). The discrete association of stone tools and bones, despite the absence of cut marks, has been interpreted as functional, despite the differences with the overlying paleosurface (e.g., where only two flakes were recovered) (Mourer-Chauviré, 1980; López Martínez, 1980; Díez, 1992).

Áridos 2 was situated about $200 \mathrm{~m}$ away from Áridos 1 (Santonja and Querol, 1980c; Santonja and Pérez-González, 2002). The site is located at the top of the stratigraphic unit of Arganda I (PérezGonzález, 1980). This unit is the top of a fluvial sequence including the units Arganda II, III and IV, spanning a thickness of $40-50 \mathrm{~m}$ in the mid- and lower valley of the Jarama river. These overlying sequences were created by the sinking of the underlying karst system composed of Miocene evaporitic rocks, which are the substrate of the Tertiary basin of Madrid in this region. Dates obtained through AAR (amino acid racemization) $(379.7 \pm 45 \mathrm{ka})$ and ESR (electron spin resonance) (384 $\pm 77 \mathrm{ka}$ ) for the Arganda I unit containing the site indicate that Áridos 2 could be assigned to the end of MIS 11 (Moreno et al., in press; Panera et al., in press). Áridos 2 correlates with the units B, C and D of the stratigraphic column documented in Áridos 1 (Fig. 1). These units are muddy overbank deposits and secondary pebble and sandy low-energy channels that existed in the wide alluvial plain of the meandriform Jarama river.

The preserved surface of this site is very small $\left(10 \mathrm{~m}^{2}\right)$ because erosion caused by two channels destroyed most of the site. In addition, modern human exploitation of the quarry altered an important part of the site (for example, half of the rib cage of the elephant was removed by the bulldozer). A partial elephant skeleton associated with 34 lithic artifacts was found on the paleo- 

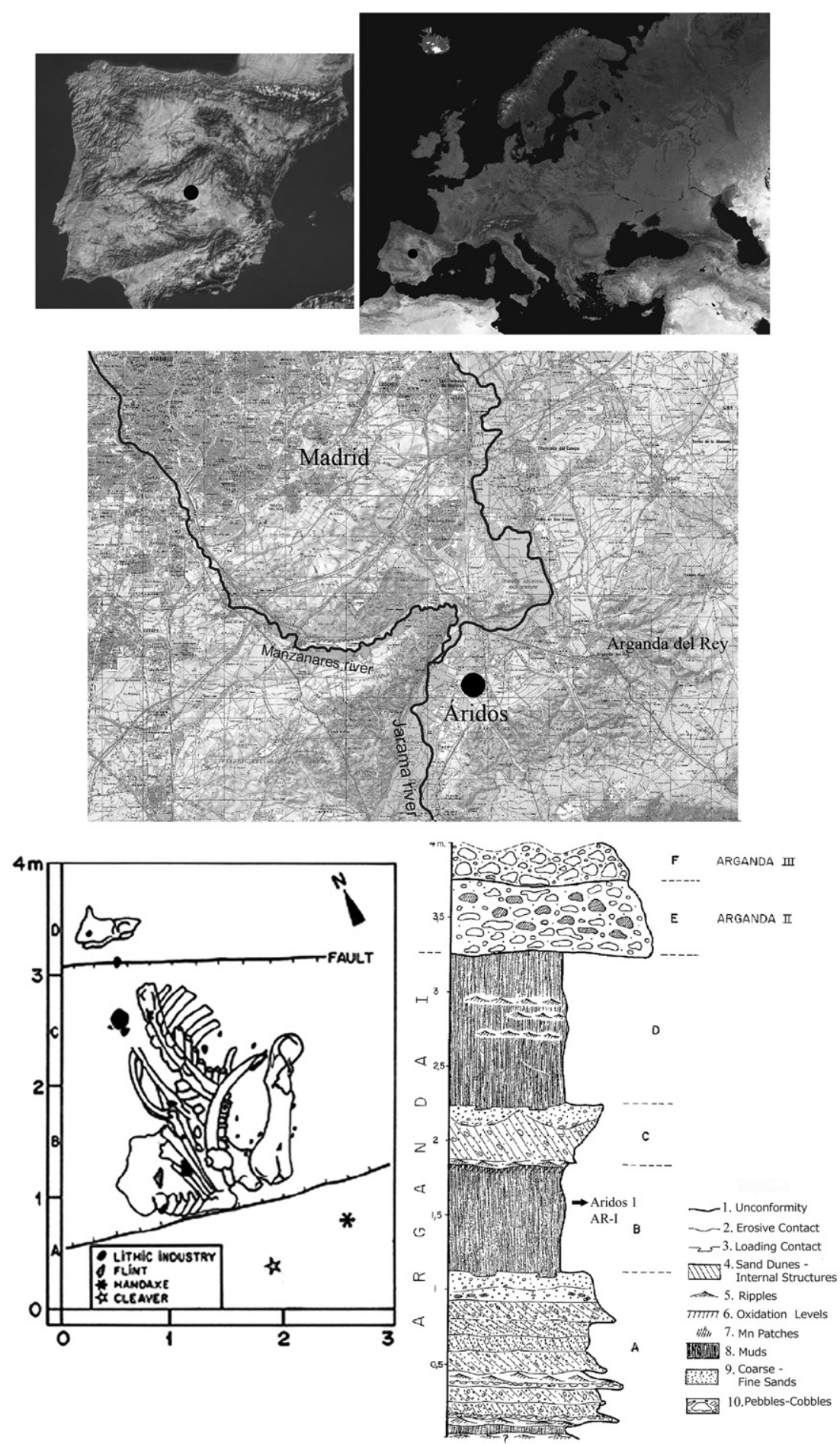

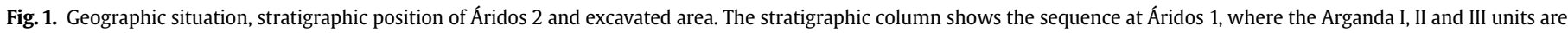
differentiated. The sandy and muddy facies (A, B, C and D) at the top of Arganda I can also be observed.

floodplain surface and overlain by sands and gravels (Santonja and Querol, 1980c). No significant sedimentary disturbance of the assemblage has been identified due to the small size of the lithic pieces and the lack of abrasion or polishing. Although two small channels were located to the east and north of the assemblage, and they contributed with sands to the local sedimentary matrix, no taphonomic indicator shows that the carcass may have been transported by any hydraulic jumble, although some rearrangement of the smaller components (e.g., lithics) and some in situ reorientation or tilting of some bones could be hypothesized. Furthermore, the identification of meat use wear polishing on the edges of several of the artifacts indicates they probably were used to butcher the elephant (Ollé Canellas, 2005). The elephant was an adult male of about 40 years, $4.6 \mathrm{~m}$ tall and almost $5000 \mathrm{~kg}$ (Soto, 1980). The stone tool assemblage is composed of 26 flakes, four cores, one burin, one backed knive, one handaxe and one cleaver.

At the end of the excavation (October, 1976), the elephant remains were covered in polyurethane to be transported in a block 


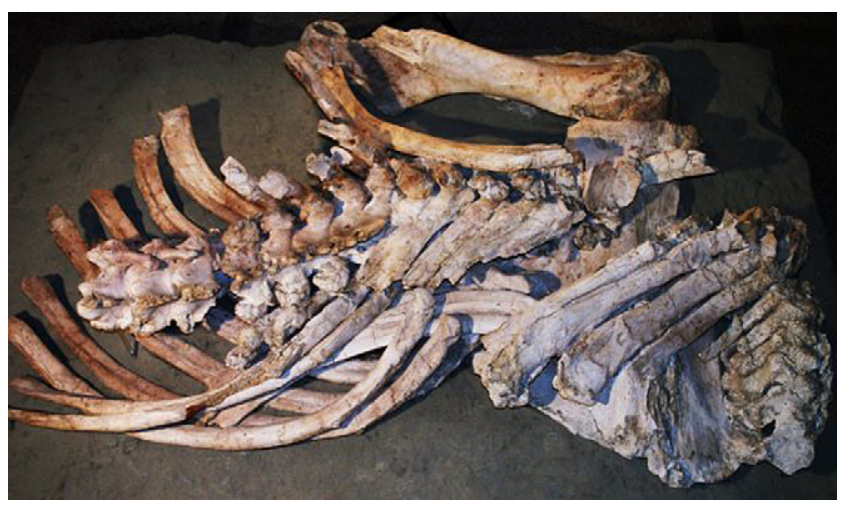

Fig. 2. Remains of the elephant carcass from Áridos 2 as are currently exhibited.

to the National Museum of Archaeology in Madrid. They were not removed from the polyurethane cast until 2002 when the Regional Archaeological Museum of Madrid restored them and the elephant was exposed at the exhibit "Handaxes and Elephants: the first inhabitants of Madrid” (Panera and Rubio-Jara, 2002a,b) (Fig. 2). This enabled its detailed taphonomic study reported here.

\section{Sample characteristics and method of analysis}

The elephant carcass is composed of a right scapula and humerus, a cranial fragment, 24 vertebrae and almost all the ribs of the right side and three of the left side. The entire assemblage is almost articulated (Figs. 1-3).

The anatomical articulation of the elephant bones in the block extracted first for transport to the museum and later, for permanent exhibit at the museum, conditioned that bone inspection could only be performed visually, without moving them from the block. Therefore, the analysis of bone surfaces was restricted to those surfaces exposed in their current position (Fig. 2). Bones were screened with hand lenses using a magnification of $10 \times, 15 \times$ and $20 \times$. Then, marks identified were molded using a fluid watercompatible high-resolution silicone (ISP 4823). The negatives were turned into positive casts with high-resolution resin (Esaflex Feropur PR 55 E-01 and Feropur E 55 E+01). The entire process was carried out under the supervision of the museum's restoration expert, since bone surfaces had been previously consolidated and the consolidating product had to be removed from the identified cut marks prior to molding them with silicone.

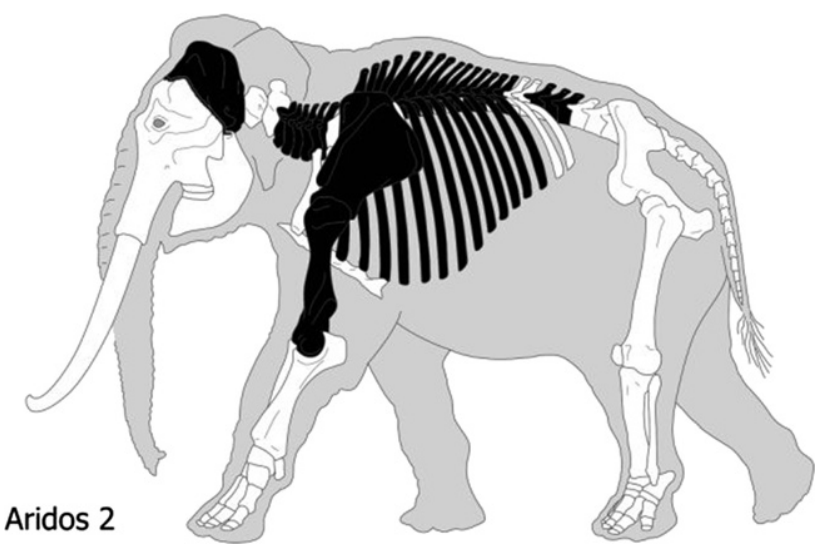

Fig. 3. Skeletal representation of the elephant carcass at Áridos 2.

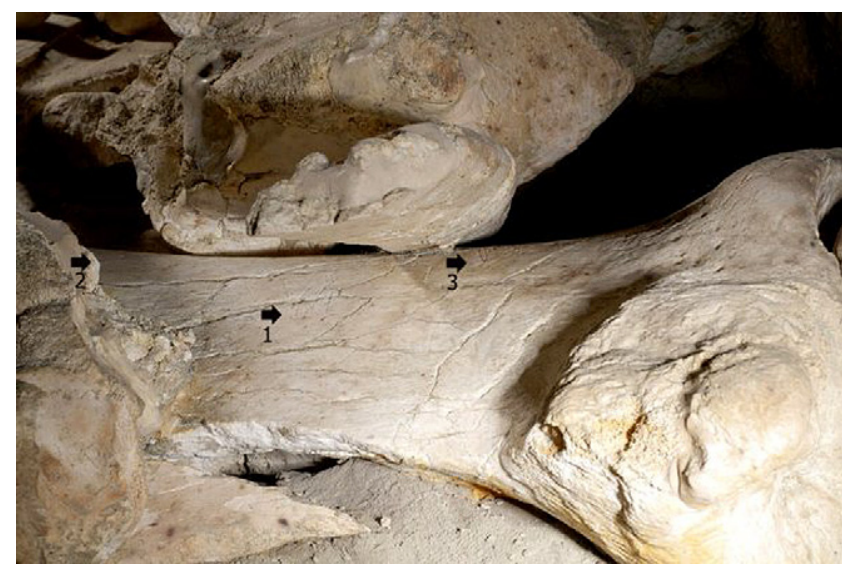

Fig. 4. Sets of cut marks on the elephant scapular surface. Arrows indicate the location of the clusters $1 \& 3$. Cluster 2 location is indicated, although it cannot be seen in this photograph.

The resin molds of cut marks were then analyzed under a binocular microscope and a SEM (Scanning Electron Microscope) at the Complutense University of Madrid.

\section{Results}

The partial elephant carcass is mainly represented by axial and cranial elements (Fig. 3). The only long bone present is a humerus. The absence of the remaining long bones cannot be explained because of the partial destruction of the site.

Several cut marks were identified on the scapular blade (Figs. 4-7) and one the ventral side of one rib (Fig. 8). Cut marks on the scapula occur in groups in three different places (Fig. 4). The first set of marks shows several deep grooves larger than $30 \mathrm{~mm}$ with an open V-shaped section. The clayish matrix of the soil filled part of the grooves (Fig. 5). The second set of marks is comprised of two straight V-shaped long grooves with a substantial amount of flaking on the shoulders (Fig. 6). A gap linked to a crack fracture intersects the cut mark. The third set of marks (Fig. 7a) is somewhat different since these are broader than the previous ones and at least two examples of fork-shaped marks, like those documented experimentally in cut marks created with a retouched edge, can be observed (Domínguez-Rodrigo et al., 2009a). Fig. 7b and c are experimentally-created cut marks made with handaxes (de Juana et al., in press). Fig. 7b shows the bifurcation of the groove causing a "fork-shaped" mark similar to the longest curvy groove located on the elephant scapula (Fig. 7a). Fig. 7c shows another

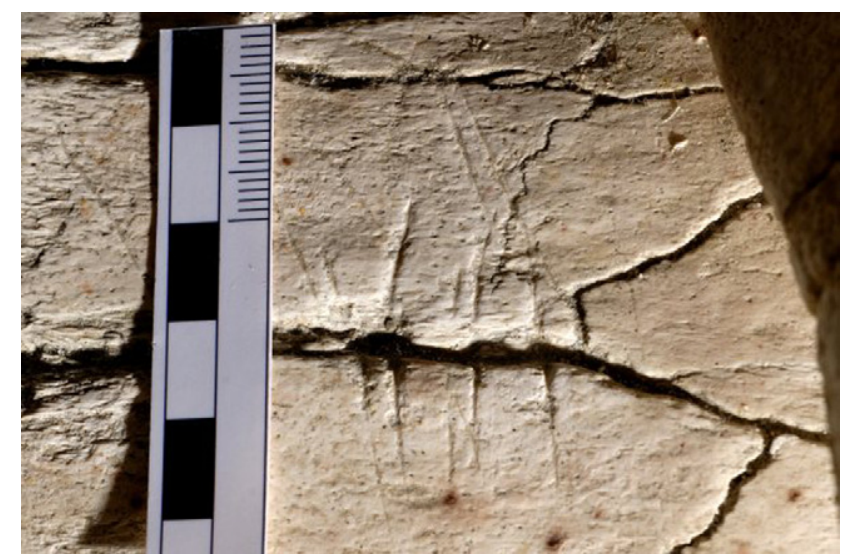

Fig. 5. Cluster 1 of cut marks on the elephant scapula. 


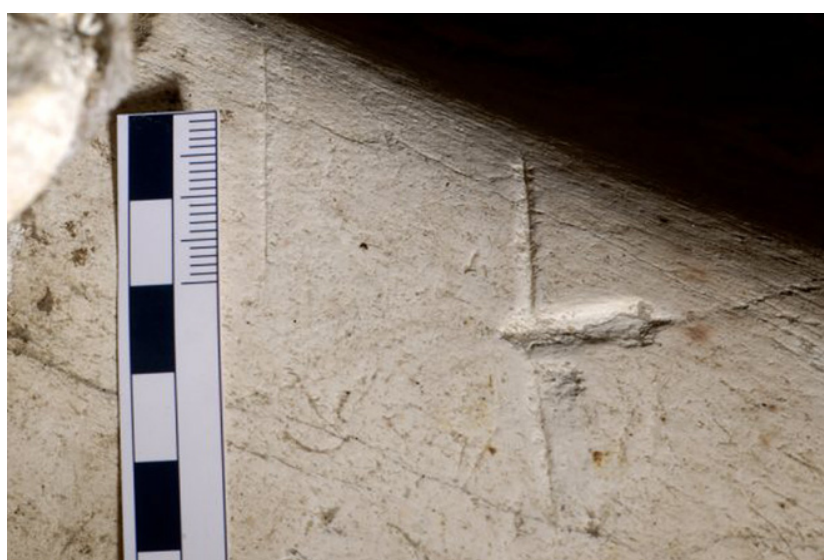

Fig. 6. Cluster 2 of cut marks on the elephant scapula.
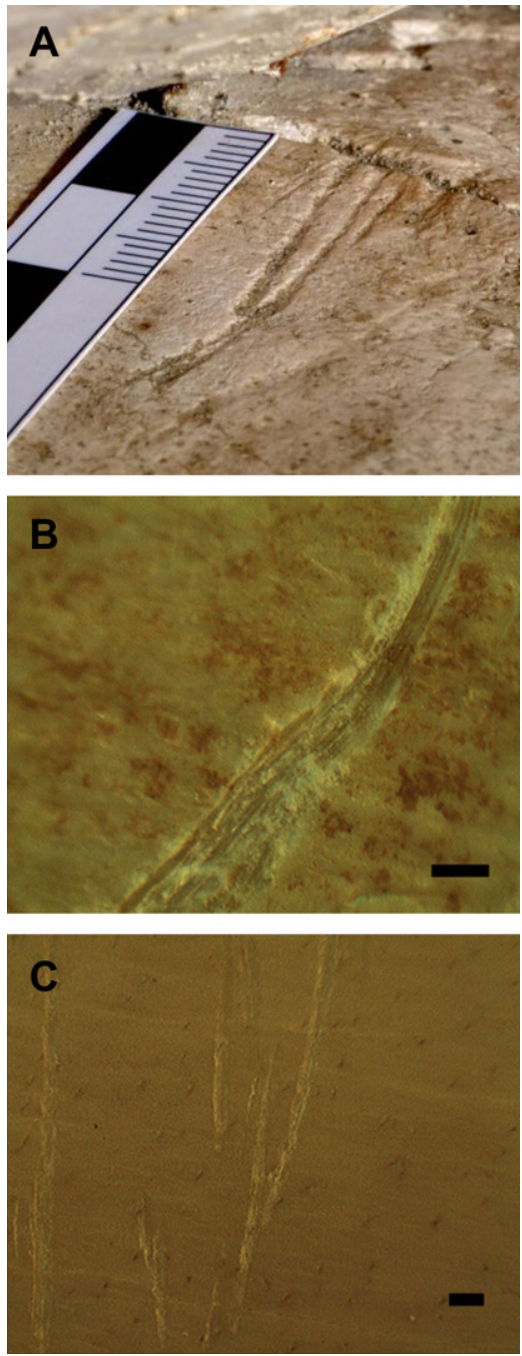

Fig. 7. A, Cluster 3 of cut marks on the Áridos 2 elephant scapula. B, experimental "fork-shaped" cut mark made with a handaxe consisting of a bifurcating groove. C, experimental "fork-shaped" cut mark made with a handaxe consisting of two joining grooves. The pattern is observed on the main long grooves to the right and also on the lower smaller grooves located to the left of the first "fork-shaped" mark. The experimental marks shown in B and C are from a single stroke. Experimental data are from de Juana et al. (in press). Scale for $7 \mathrm{~b}$ and $7 \mathrm{c}$ is $1 \mathrm{~mm}$.
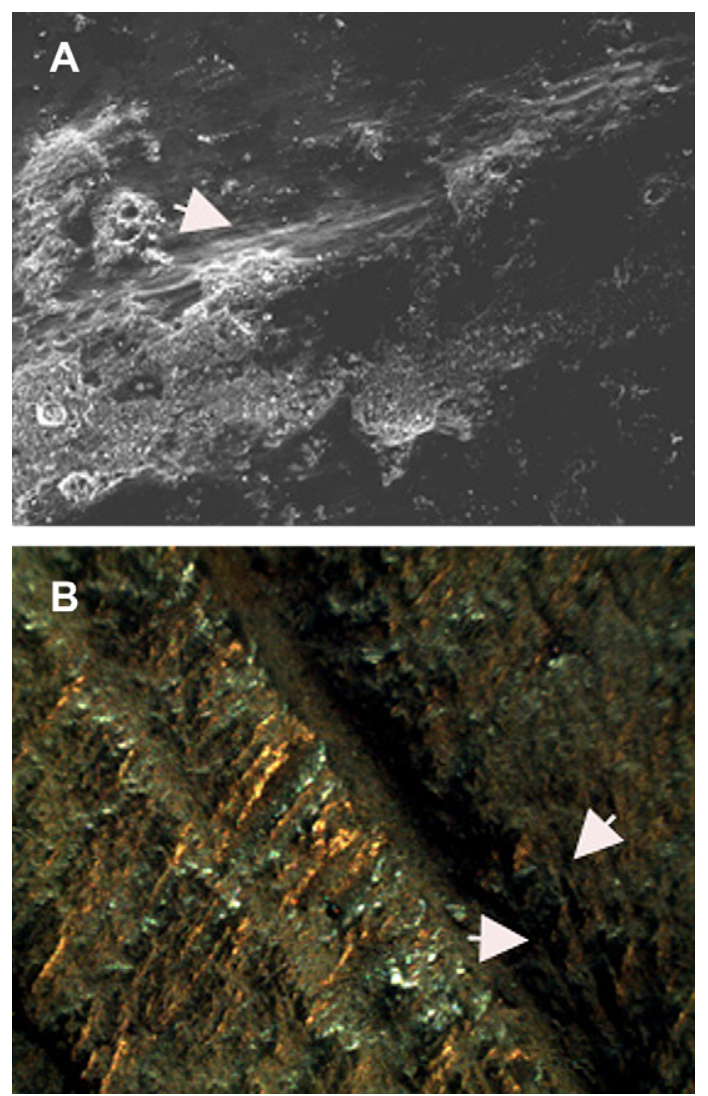

Fig. 8. A, S.E.M. image $(100 \times)$ showing a portion of one of the cut marks displaying some microstriations (arrow) at the base on the groove, close to the wall of the mark where some hertzian cones can also be documented. B, another cut mark showing a Vshaped section with accompanying shoulder effect (broader shallower groove to the left) where some microstriations (arrows) are documented both on the internal side of the wall and the edge of the mark. This image has been obtained by using a binocular microscope $(20 \times)$ on the high-resolution positive mold of the mark prepared for S.E.M. inspection.

pattern of "fork-shaped" marks created by the junction of two independent grooves created by a single stroke, as documented in the two longest grooves from the set of marks on the elephant scapula. In addition, the absolute widths of several grooves (see scale in Figs. 4-7) exceed the dimensions of marks made with simple or retouched flakes (Domínguez-Rodrigo et al., 2009a) and are similar to those reported for cut marks made with handaxes (de Juana et al., in press). This interpretation is further supported by the discovery of meat use wear polish on the spatially associated handaxe that was found near the elephant remains (Ollé Canellas, 2005). Mark section shape, the intensity of flaking on the shoulder of some of the marks, and the straight trajectory of the marks are criteria that clearly identify these marks as cut marks instead of trampling marks. This is further supported by the absence of oblique intersecting striations and the micro-abrasion marks which occur in almost $100 \%$ of cases where bones are trampled (Domínguez-Rodrigo et al., 2009a). Furthermore, although bone preservation is very poor (Fig. 8) and a lot of microflaking caused by bone modification has removed most of the original microstriations, high magnification is useful to spot some remnants of the original striated groove. Fig. 8 captures some of the microstriations that have survived in only a portion of the main body of the groove, showing that an abrasive agent (e.g., stone tool edge) created the wide mark.

Cut marks on the rib form two sets. The left set is composed of few and widely spaced marks with V-shaped straight trajectories 


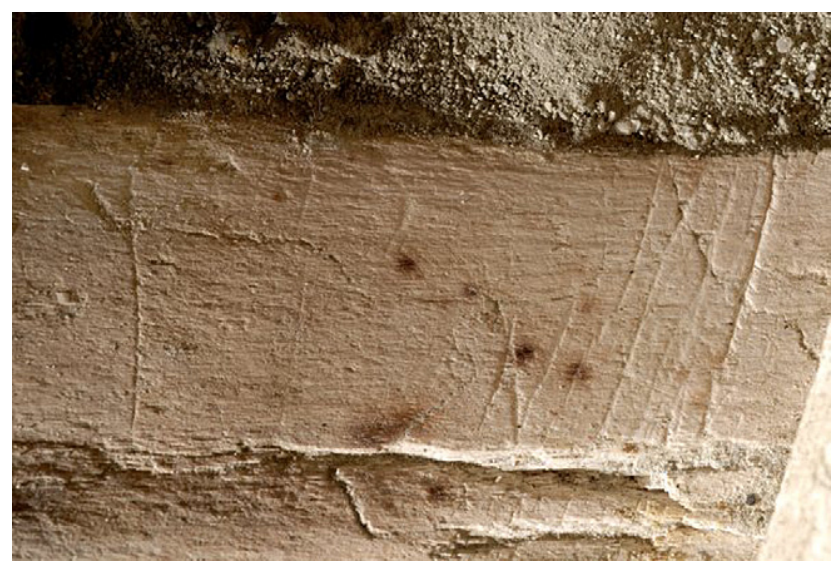

Fig. 9. Cut marks on the ventral side of the elephant rib.

and the right set has several parallel marks, all of them V-shaped, some with intensive flaking on the edge (Fig. 9). These characteristics as well as the presence of the bulk of the axial skeleton above this rib prevents them from having been caused by trampling. The presence of these cut marks on the ventral side of the ribs suggest that they were caused during evisceration. This is important since evisceration, even in a carcass this size, occurs in the earliest stages of its consumption by carnivores. Therefore, this may be suggestive of hominins having had access to this carcasses either before carnivores did or at the very early stages of carcass consumption (Fig. 10).

Most of the cut marks show all the characteristics of cut marks made with simple flakes or with tools whose edges have not been retouched. Only the third set of marks on the scapula seems to have been made with a retouched tool, given its broad section shape and the intersecting fork-shaped pattern. This feature, together with the absolute width of the grooves, supports the hypothesis that these marks may have been created with handaxes or large retouched tools (Domínguez-Rodrigo et al., 2009a,b). This functional interpretation of the lithic tools and the taphonomic data reported here is also supported by the use-wear analysis of part of the lithic assemblage assemblage (Ollé Canellas, 2005, 419-441).

In addition to the anthropogenic exploitation of the elephant, carnivore intervention has also been detected. Several tooth marks

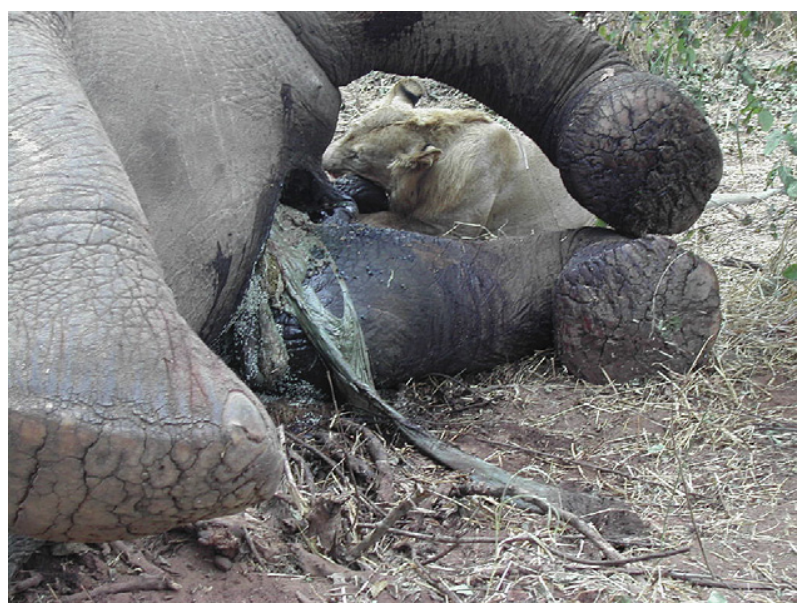

Fig. 10. Elephant carcass at the initial stage of being scavenged by lions. Eventration has already taken place at this early stage where meat has not been targeted yet. Obtained at Tarangire National Park (photo: Agness Gidna).

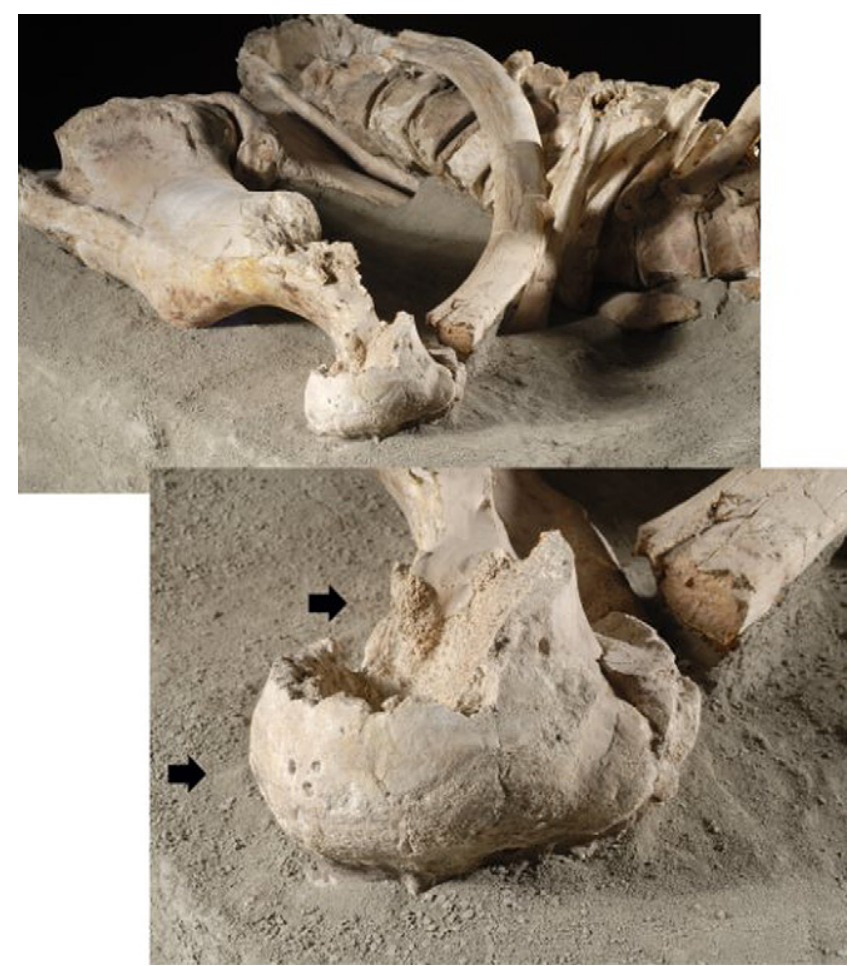

Fig. 11. Distal humerus epiphyseal end and metadiaphysis showing gnawing. Lower image shows a close-up detail of the distal epiphysis.

have been identified together with intense furrowing on the distal epiphysis of the humerus (Fig. 11). The size of the tooth pits as well as the degree of furrowing clearly identify hyenids as the carnivores responsible for these modifications. Some chewing on one rib end has also been observed.

\section{Conclusions}

Cut marks have been found on the scapula and one rib of the elephant at Áridos 2, indicative of butchery and involving both defleshing and evisceration. This is suggestive of early access to the carcass by hominins. Haynes (2005) shows that viscerae disappear fast in the consumption of elephant carcasses by carnivores. This is also indicative of large carcass consumption during the Middle Pleistocene by hominins, not solely restricted to the Upper Pleistocene (Gaudzinski et al., 2005; Surovell and Waguespack, 2008). The evidence from Áridos 2 can be added to similarly documented elephant butchery behaviors taphonomically reported in sites such as Ambrona (Villa et al., 2005), Gesher Benot Ya'akov (Goren-Inbar et al., 1994), La Cotte de St Brelade (Scott, 1986) and other sites where, even if cut-marked bone is absent, such as at Lerhingen (Thieme and Veil, 1985) and Gröbern (Weber, 2000), the tight spatial association of elephant carcass remains and stone tools, as well as the presence of a fragment of a wooden spear, are suggestive of exploitation of these carcass remains by hominins. It is obviously difficult to assess whether these resources were acquired through hunting or scavenging (Fosse, 1998; Mussi, 2005). Arguments supporting both options are available (Villa and Lenoir, 2009). The natural deposition of carcasses at Ambrona with their occasional exploitation by hominins has been defended by Villa et al. (2005). The much more spatially discreet accumulation found in La Cotte de St Brelade with better taphonomically-supported evidence of repeated butchery of most of the individuals represented in the accumulation, as well as the location of the site at the foot of a cliff, 
are better understood as the result of an intentionally active acquisition strategy displayed by hominins (Scott, 1986).

One way or another, what is becoming relevant is that the exploitation of elephant and other large carcasses during the Middle Pleistocene (e.g., woolly rhinoceros at La Cotte de St Brelade (Scott, 1986) and Boxgrove (Parfitt and Roberts, 1998)) was more than a marginal strategy of protein obtainment by hominins. This is documented not only at European sites but also at African sites, such as several Middle Pleistocene sites in Middle Awash, where remains of hippopotamus occur in association with stone tools, several of them bearing cut marks (de Heinzelin et al., 2000). Exploitation of resources from these large animals has also been documented earlier in Africa, during the Lower Pleistocene. For example, several cut-marked hippopotamus bones have been documented at Buia (Fiore et al., 2004) and even earlier at Koobi Fora (Bunn, 1994). However, the evidence of consumption of these animals prior to $1 \mathrm{Ma}$ is so scanty that there are no arguments supporting anything but a marginal and irregular exploitation of these carcasses at that time. Exploitation of animals larger than $1000 \mathrm{~kg}$ has also been documented at BK (Upper Bed II, Olduvai Gorge, Tanzania) at around $1.2 \mathrm{Ma}$ (Domínguez-Rodrigo et al., 2009b). Beyond documenting the inclusion of faunal taxa larger than $1000 \mathrm{~kg}$ in the diet of hominins, archaeologists are faced now with the need to explain why consuming resources from such large animals becomes more visible after the end of the Lower Pleistocene in the archaeological record.

The discovery of a butchered elephant at Áridos 2 reported in the present work is relevant because it shows one of the earliest pieces of evidence of this type of behavior associated with an Acheulian site and where a convincing case can be made for handaxe use for butchery of a proboscidean carcass.

\section{Acknowledgements}

We wish to thank Antonio Dávila, Javier Casado and Mario Torquemada from the Regional Archaeological Museum of Alcalá de Henares (Madrid) for their help and assistance in the study of the elephant remains from Áridos 2. Special thanks go to Pilar Rodríguez Frade for her excellent restoration work, which despite the overall poor bone cortical condition preserved the cut marks reported in the present work. MDR thanks M. Prendergast for her editorial help and unfailing support. We are indebted to T.R. Pickering, M. I. Erin and one anonymous reviewer for their very valuable comments to an earlier draft of this paper.

\section{References}

Anconetani, P., Díez, C., Rosell, J., 1996. Intentional bone fracturing for marrow extraction in Atapuerca (Spain) and Isernia la Pineta (Italy). Lower Palaeolithic sites. In: III International Congress of Prehistoric and Protohistoric Sciences. Forli 8-14 September, Tome 2, 445-451.

Anzidei, A.P., Cerilli, E., 2001. The fauna of La Polledrara di Cecanibbio and RebibbiaCasal de'Pazzi (Rome, Italy) as an indicator for site formation processes in a fluvial environment. In: Cavarretta, G., Gioia, P., Mussi, M., Palombo, M.R. (Eds.), Proceedings of the First International Congress. The World of Elephants. Consiglio Nazionale delle Ricerche, Rome, pp. 167-171.

Binford, L.R., 1987. Were there elephant Huntersat Torralba? In: Nitecki, M.H., Nitecki, D. (Eds.), The Evolution of Human Hunting. Plenum Press, New York, pp. 47-105.

Bunn, H.T., 1982. Meat-eating and Human Evolution: Studies on the Diet and Subsistence Patterns of Plio-Pleistocene Hominids in East Africa. Ph. dissertation. University of California, Berkeley.

Bunn, H.T., 1994. Early Pleistocene hominid foraging strategies along the ancestral Omo River at Koobi Fora, Kenya. Journal of Human Evolution 27, 247-266.

Butzer, K.W., 1972. Environment and Archaeology: An Ecological Approach to Prehistory. Methuen, Londres.

Cerralbo, Marqués de, 1913. Torralba, la plus ancienne station humaine de l'Europe? In: Congrès International du Anthropologie et d'Archéologie Préhistoriques (Genéve 1912). Comptes rendues, XIV Session:277-290.
Crader, D.C., 1983. Recent single-carcass bone scatters and the problem of "butchery" sites in the archaeological record. BAR International Series163. In: Clutton-Brock, J., Grigson, C. (Eds.), Animals and Archaeology. Hunters and Their Prey, vol. 1, pp. 107-141.

Díez, J.C., 1992. Zooarqueología de Atapuerca (Burgos), e implicaciones paleoconómicas del estudio tafonómico de yacimientos del Pleistoceno Medio. Tesis doctoral. Universidad Complutense de Madrid.

Domínguez-Rodrigo, M., 2008. Butchery and kill sites. In: Pearsall, D.M. (Ed.), Encyclopedia of Archaeology. Academic Press, New York, pp. 948-953.

Domínguez-Rodrigo, M., Barba, R., Egeland, C.P., 2007. Deconstructing Olduvai. A taphonomic Study of the Bed I Sites. Vertebrate Paleobiology and Paleonthropology Series. Springer, New York.

Domínguez-Rodrigo, M., De Juana, S., Galán, A.B., Rodríguez, M., 2009a. A new protocol to differentiate trampling marks from butchery cut marks. Journal of Archaeological Science 36, 2643-2654.

Domínguez-Rodrigo, M., Mabulla, A., Bunn, H.T., Barba, R., Diez-Martin, F., Egeland, C.P., Espilez, E., Egeland, A., Yravedra, J., Sanchez, P., 2009b. Unraveling hominin behavior at another anthropogenic site from Olduvai Gorge (Tanzania): new archaeological and taphonomic research at BK, Upper Bed II. Journal of Human Evolution 57, 260-283.

Fiore, I., Bondolli, L., Coppa, A., Macchiarelli, R., Russom, R., Kashay, H., Solomon, T., Rook, L., Libsekal, Y., 2004. Taphonomic analysis of the late early Pleistocene bone remains from Buia (Dandero Basin, Danakil Depression, Eritrea): evidence for large mammal and reptile butchery. Rivista Italiana di Paleontologia e Stratigrafia 110, 89-97.

Fosse, P., 1998. Les probóscides dans les sites archéologiques de plein air paléolithiques origine antropologique ou naturalle? In: XVIII Rencontres internationale d'Archeologie et d'hisire d'Antibes- Octubre, 1997. p. 105-117.

Freeman, L.G., 1994. Torralba and Ambrona: a review of discoveries. In: Corruccini, R.S., Ciochon, R.L. (Eds.), Integrative Paths to the Past. Prentice Hall, Englewood Cliffs, New Jersey, pp. 597-637.

Frison, G.C., 1989. Experimental use of Clovis Weaponry and tools on African elephants. American Antiquity 54, 766-784.

Frison, G.C., Todd, L.C., 1986. The Colby Mammoth Site. University of New Mexico Press, Albuquerque.

Gaudzinski, S., Turner, E., Anzidei, A.P., Á lvarez-Fernández, E., Arroyo-Cabrales, J., Cinq-Mars, J., Dobosi, V.T., Hannus, A., Johnson, E., Münzel, S.C., Scheer, A., Villa, P., 2005. The use of Proboscidean remains in every-day Palaeolithic life. Quaternary International 126-128, 179-194.

Goren-Inbar, N., Lister, A., Werker, E., Chech, M., 1994. A butchered elephant skull and associated artifacts from the Acheulian site of Gesher Benot Ya'akov, Israel. Paleorient 20, 99-112.

Haynes, G., 1991. Mammoths, Mastodonts, and Elephants: Biology, Behaviour and the Fossil record. Cambridge University Press, Cambridge.

Haynes, G., 2005. Las acumulaciones modernas de huesos de elefantes como modelo para interpretar Ambrona y otras áreas con fauna fósil a orillas del agua. In: Santonja, M., Pérez González, A. (Eds.), Los yacimientos paleolíticos de Ambrona y Torralba (Soria). Zona Arqueológica 5, Alcalá de Henares, pp. 154-174.

de Heinzelin, J., Clark, J.D., Schick, K.D., Gilbert, W.H. (Eds.), 2000, The Acheulean and the Plio-Pleistocene deposits of the Middle Awash valley Ethiopia, vol. 104 Royal museum of Central Africa, Belgium, pp. 193-202. Annales Sciences Géologiques.

Howell, F.C., 1966. Early Man. Time-Life Int., The Netherlands.

Howell, F.C., Butzer K.W., Freeman L.G., Klein R.G., 1995. Observations on the Acheulean Occupation Site of Ambrona (Soria Province, Spain), with Particular Reference to Recent Investigation (1980-1983) and the Lower Occupation. Jahrbuch des Römisch-Germanischen Zentralmuseum Mainz, 38:33-82.

Iakovlevaa, L.B., Djindjian, F., 2005. New data on Mammoth bone settlements of Eastern Europe in the light of the new excavations of the Gontsy site (Ukraine). Quaternary International 126-128, 195-207.

de Juana, S., Galán, A.B. and Domínguez-Rodrigo, M. Taphonomic identification of cut marks made with lithic handaxes: an experimental study. Journal of Archaeological Science, in press.

Leakey, M.D., 1971. Olduvai Gorge. In: Excavations in Beds I and II, 1960-1963, vol. 3. Cambridge University Press, Cambridge.

López Martínez, N., 1980. Los Micromamíferos (Rodentia, Insectivora, Lagomorpha y Chiroptera) del sitio de ocupación achelense de Áridos-1 (Arganda, Madrid). In: Santonja, M., López, N., Pérez-González, A. (Eds.), Ocupaciones achelenses en el Valle del Jarama (Arganda, Madrid). Arqueología y Paleoecología, I, Diputación Provincial de Madrid, pp. 161-202.

Mania, D. 1990. Auf der Spuren der Urmenschen: die Funde von Bilzingsleben. Theiss, Berlin.

Martos, J.A., 1998. Elefantes e intervención humana en los yacimientos del Pleistoceno Inferior y Medio de África y Europa. Trabajos de Prehistoria 55 (1), 19-38.

Maschenko, E.N., Pavlov, A.F., Zenin, V.N., Leshchinskiy, S.V., Orlova, L.A., 2003. The Lugovskoe site: relations between the mammoth assemblage and late Paleolithic Man (L). In: Proceedings of 3rd International Mammoth Conference-Abstracts Volume, Dawson City, Yukon Territory, Canada. 77-80.

Moncel, M.H., 2001. Microlithic Middle Palaeolithic assemblages in Central Europe and elephants remains. Atti del 1 Congreso International. In: Procedings in the 1 St International Congress. In: Cavarreta, G. (Ed.), La Terra degli elefanti (The world of elephants), pp. 314-317. 
Moreno, D., Panera, J., Rubio-Jara, S., Duval, M., Falguères, C., Pérez-González, A., Voinchet, P., Bahain, J.J., Sala, R. Datation ESR des sites archéologiques en contexte fluviatile de la région de Madrid (Espagne). Bio-géosystèmes continentaux quaternaires: variabilité climatique et anthropisation. In: Colloque « Quaternaire » Q7 Besançon 17-19 février, 2010, in press.

Mourer-Chauviré, C., 1980. Las Aves del sitio de ocupación achelense de Áridos-1 (Arganda, Madrid). In: Santonja, M., López, N., Pérez-González, A. (Eds.), Ocupaciones achelenses en el Valle del Jarama (Arganda, Madrid). Arqueología y Paleoecología, I, Diputación Provincial de Madrid, pp. 145-160.

Mussi, M., 2005. Hombres y Elefantes en las latitudes medias: una larga convivencia. In: Santonja Gómez, M., Pérez-González, A. (Eds.), Los Yacimientos Paleolíticos de Ambrona y Torralba. Zona Arqueológica, vol. 5. Museo Arqueológico Regional, Madrid, pp. 396-417.

Mussi, M., Villa, P., 2008. Single carcass of Mammuthus primigenius with lithic artifacts in the Upper Pleistocene of northern Italy. Journal of Archaeological Science 35, 2606-2613.

Nývltová Fišáková, M., 2005. Faunal remains from the sites of Spytihněv-Duchonce, Jarošov-Kopaniny and Napajedla-Brickyard. Dolnověstonické studie 13, Brno. In: Škrdla, P. (Ed.), Upper Paleolithic on the Middle Course of the Morava River, pp. 217-221.

Ollé Canellas, A. 2005. Variabilitat i patrons funcionals en els sistemes tècnics de mode 2. Anàlisi de les deformacions d'ús en els conjunts lítics del Riparo Esterno de Grotta Paglicci (Rigano Garganico, Foggia), Aridos (Arganda, Madrid) i Galeria-TN (Atapuerca, Burgos). Tesis doctoral. Universitat Rovira i Virgili. $<$ http://www.tdx.cesca.es/TDX-0701105-120553/>.

Panera, J., Torres, T., Pérez-González, A., Ortiz Menéndez, J.E., Rubio-Jara S., Uribelarrea del Val, D. Geocronología de la Terraza Compleja de Arganda en el valle del río Jarama (Comunidad de Madrid). Revista de la Sociedad Geológica de España, in press.

Panera, J., Rubio-Jara, S. (Eds.), 2002a. Bifaces y Elefantes. Zona Arqueológica. 1, Alcalá de Henares, Madrid.

Panera, J., Rubio-Jara, S., 2002b. Bifaces y Elefantes. Los primeros pobladores de Madrid. Catálogo de la exposición (October-December 2002). Museo Arqueológico Regional, Madrid.

Parfitt, S., Roberts, M., 1998. Boxsgrove: A Middle Pleistocene Hominid Site at Eartham Quarry, Boxgrove, West Sussex English Heritage Report, London.

Pérez-González, A., 1980. El marco geográfico, geológico y geomorfológico de los yacimientos de Áridos en la cuenca del Tajo. In: Santonja, M., López, N., PérezGonzález, A. (Eds.), Ocupaciones achelenses en el valle del Jarama (Arganda, Madrid). Arqueología y Paleoecología, I, Diputación Provincial de Madrid, pp. 15-28.

Pérez-González, A., Uribelarrea, D., 2002. Geología del Cuaternario de los valles fluviales del Jarama y Manzanares en las proximidades de Madrid. In: Panera, J., Rubio-Jara, S. (Eds.), Bifaces y Elefantes. Zona Arqueológica. 1, pp. 302-317.

Pitti, C., Radmilli, A.M., 1984. La stazione del Paleolitico inferiore a Castel di Guido presso Roma. Atti XXIV Riunione Scient. Ist. Ital. Preist. Protost., 73-87.

Radmilli, A.M., Boschian, G., 1996. Gli scavi a Castel di Guido. Instituto Italiano di Preistoria e Protostoria, ETS, Firenze.

Santonja, M., López, N., Querol, M.A., Soto, E., 1980a. Estudio de las dispersiones de industria lítica y de los restos de vertebrados en Áridos-1 (Arganda, Madrid). In: Santonja, M., López, N., Pérez-González, A. (Eds.), Ocupaciones achelenses en el valle del Jarama (Arganda, Madrid). Arqueología y Paleoecología I, Diputación Provincial de Madrid, pp. 279-295.

Santonja, M., Villa, P, Soto, E. and Sesé, C. 2001. Elephants in the archaeological sites of Aridos (Jarama Valley, Madrid, Spain). The world of elephants. In: Proceedings of the Ist International Congress, Roma:602-606.

Santonja, M., Pérez-González, A., 2002. El Paleolítico inferior en el interior de la Península ibérica. Un punto de vista desde la geoarqueología. Zephyrus 53-54, 27-77.

Santonja, M., Querol, M.A., 1980a. Características de la ocupación humana en los suelos achelenses de la terraza de Áridos (Arganda, Madrid). In: Santonja, M. López, N., Pérez-González, A. (Eds.), Ocupaciones achelenses en el valle del
Jarama (Arganda, Madrid). Arqueología y Paleoecología, I, Diputación Provincial de Madrid, pp. 321-336.

Santonja, M., Querol, M.A., 1980b. Yacimientos de la terraza de Áridos: proceso de excavación. In: Santonja, M., López, N., Pérez-González, A. (Eds.), Ocupaciones achelenses en el valle del Jarama (Arganda, Madrid). Arqueología y Paleoecología, I, Diputación Provincial de Madrid, pp. 63-75.

Santonja, M., Querol, M.A., 1980c. El sitio de ocupación achelense de Áridos-2. Descripción general y estudio de la industria lítica. In: Santonja, M., López, N Pérez-González, A. (Eds.), Ocupaciones achelenses en el valle del Jarama (Arganda, Madrid). Arqueología y Paleoecología I, Diputación Provincial de Madrid, pp. 297-306.

Santonja, N., López, A., Pérez-González, A., 1980b. Ocupaciones achelenses en el valle del Jarama (Arganda, Madrid). Arqueología y Paleoecología, I, Diputación Provincial de Madrid.

Schreve, D.C., 2006. The taphonomy of a Middle Devensian (MIS 3) vertebrate assemblage from Lynford, Norfolk, UK, and its implications for Middle Palaeolithic subsistence strategies. Journal of Quaternary Science 21, 543-556.

Scott, K., 1986. The bone assemblages of layers 3 and 6. In: Callow, P., Cornford, J. M. (Eds.), La Cotte de St. Brelade, 1961-1978. Geo Books, Norwich, pp. 159-183.

Sesé, C., Soto, E., 2002. Vertebrados del Pleistoceno del Jarama y el Manzanares. Madrid. In: Panera, J., Rubio, S. (Eds.), Bifaces y Elefantes. Zona Arqueológica 1, pp. 302-318.

Shipman, P., 1986. Scavenging or hunting in early hominids: theorical frameworks and tests. American Antropologist 88, 27-43.

Shipman, P., Rose, J., 1983. Evidence of butchery and hominid activities at Torralba and Ambrona: an evaluation using microscopic techniques. Journal of Archaeological Science 10, 465-474.

Soto, E., 1980. Artiodáctilos y Proboscidios de los yacimientos de Áridos de Arganda (Madrid). In: Santonja, M., López, N., Pérez-González, A. (Eds.), Ocupaciones achelenses en el valle del Jarama (Arganda, Madrid). Arqueología y Paleoecología I, Diputación Provincial de Madrid, pp. 207-229.

Sousa, M.F. Figueiredo, S.M. 2001. The Pleistocene elephants of Portugal. In: Cavarreta, G., et al. (Eds.), Proceedings of the I Int. Congress "The World of Elephants". Comune di Roma, C.N.R, Ministero per i Beni e le Attività Culturali, Università di Roma, Roma.

Surovell, T.A., Waguespack, N.N., 2008. How many elephant kills are 14? Quaternary International 191, 82-97.

Svoboda, J., Péan, S., Wojtal, P., 2005. Mammoth bone deposits and subsistence practices during Mid-Upper Palaeolithic in Central Europe: three cases from Moravia and Poland. Quaternary International 126-128, 209-221.

Thieme, H., Veil, S., 1985. Neue Untersuchungen zum eemzeitlichen ElefantenJagdplaz Lehringen. Ldkr. Verden. Die Kunde N. F 36, 11-58.

Villa, P., 1990. Torralba and Aridos: elephant exploitation in Middle Pleistocene Spain. Journal of Human Evolution 19, 299-309.

Villa, P., Soto, E., Pérez-González, A., Santonja, M., Mora, R., Parcerisas, Q., Sese, C., 2005. New data from Ambrona (Spain): closing the hunting versus scavenging debate. Quaternary International 126-128, 223-250.

Villa, P., Lenoir, M., 2009. Hunting and hunting weapons of the Lower and Middle Paleolithic of Europe. In: Richards, M., Hublin, J.J. (Eds.), The Evolution of Hominid Diet: Integrating Approaches to the Study of Palaeolithic Subsistence. Springer, New York, pp. 59-84.

Weber, T., 2000. The Eemian Elephas antiquus finds withartifacts from Lehringen and Gröbern: are they really killing sites? Anthropologie et Préhistoire 111, 177-185.

Zbyszewski, G., 1943. "Les eléphants quaternaires du Portugal”. Comunicações dos Serviços Geológicos de Portugal 24, 71-89.

Zenin, V.N., Maschenko, E.N., Leshchinskiy, S.V., Pavlov, A.F., Grootes, P.M., Nadeau, M.J., 2003. The first direct evidence of mammoth hunting in Asia (Lugovskoye site, western Siberia). In: Proceedings of 3rd International Mammoth Conference. Abstracts Volume. Dawson City, Yukon Territory, Canada. 152-155. 